\title{
Protagonistas de séries voltadas para a aprendizagem de alemão: uma análise da representação de falantes interculturais
}

\author{
[Protagonists from webseries aimed at the learning of German: a review of the \\ representation of intercultural speakers] \\ http://dx.doi.org/10.11606/1982-88372135170
}

\section{Arthur Heredia Crespo ${ }^{1}$ \\ Cibele Cecilio de Faria Rozenfeld ${ }^{2}$}

\begin{abstract}
Audiovisual material, such as movies and series, give the teacher the opportunity to point out different types of the target language speakers: native speakers (commonly taken as example) and intercultural speakers (HOUSE 2007). Such non-native speakers are the ones who take proper use of the foreign language to communicate. Introducing non-native speakers to the student is importante so they can break the concept of the native speaker as an ideal learning model (RAJAGOPALAN 2012); due to this reason it's indispensable to have this kind of character properly represented in series and movies. Bearing this in mind, we aim to analyze, in this paper, the series Erste Wege in Deutschland and Jojo sucht das Glück, regarding their main characters (both supposedly intercultural speakers). Two and five episodes from these series respectively have been analyzed, in order to reflect on the main characters, based on the characterization of intercultural speaker from related studies (BYRAM, GRIBKOVA AND STARKEY 2002; HOUSE 2007; OLIVEIRA 2012). The results point out to a superficial representation of these characters, once they reproduce, in general, typical characteristics of an ideal speaker, which creates stereotyped images of the target language.
\end{abstract}

Keywords: teaching and learning of german, intercultural learning, intercultural speaker, audiovisual materials

Resumo: Os materiais audiovisuais, como filmes e seriados, proporcionam ao professor a oportunidade de apontar exemplos de diferentes tipos de falantes da língua-alvo: tanto falantes nativos (comumente tomados como modelo) quanto interculturais (HOUSE 2007), sendo estes falantes não nativos que se apropriaram adequadamente da língua estrangeira para a comunicação. Apresentar falantes interculturais ao aluno é importante para que ele possa romper com a concepção de falante nativo ideal como modelo de aprendizagem (RAJAGOPALAN 2012); por essa razão, é imprescindível que esse tipo de personagem seja representado adequadamente em

\footnotetext{
${ }^{1}$ Universidade Estadual Paulista Júlio de Mesquita, Faculdade de Ciências e Letras, Campus Araraquara, Rodovia Araraquara - Jaú, km 1, Bairro dos Machados, Araraquara, São Paulo, 14800-901. E-mail: arthurherediacr@gmail.com

${ }^{2}$ Universidade Estadual Paulista Júlio de Mesquita, Faculdade de Ciências e Letras, Campus Araraquara, Rodovia Araraquara - Jaú, km 1, Bairro dos Machados, Araraquara, São Paulo, 14800-901. E-mail: cibeleroz@gmail.com
}

\section{(cc) BY-NC}


Crespo, A.H.; Rozenfeld, C. - Protagonistas de séries voltadas para a aprendizagem de alemão

seriados e filmes. Tendo isso em vista, pretendemos analisar, neste trabalho, os seriados Erste Wege in Deutschland e Jojo sucht das Glück, no que se refere a suas protagonistas (ambas, supostamente, falantes interculturais). Foram analisados, respectivamente, dois e cinco episódios das séries, buscando refletir sobre as protagonistas com base na caracterização de falante intercultural nos estudos da área (BYRAM, GRIBKOVA E STARKEY 2002; HOUSE 2007; OLIVEIRA 2012). Os resultados apontam para uma representação artificial dessas personagens, pois elas reproduzem, de forma geral, características típicas de um falante idealizado, o qual gera imagens estereotipadas da língua-alvo.

Palavras-chave: ensino e aprendizagem de alemão, ensino intercultural, falante intercultural, materiais audiovisuais

\section{Introdução}

Diversos autores têm apontado os benefícios do uso de materiais audiovisuais na Educação (MorÁN 1995; STEFANi 2010; Pires 2011; MARQues; RoZENFELd 2018), dentre os quais se destacam o aumento da motivação dos alunos (DÖRNYEI 1994) e o desestranhamento da cultura-alvo (ROZENFELD; VIANA 2011). Somado a isso, defendese, em estudos contemporâneos do campo do ensino e aprendizagem de LE, o uso de uma abordagem intercultural que possibilite o desenvolvimento do aluno como um indivíduo capaz de se posicionar no mundo globalizado e plural (OLIVEIRA 2012).

Diante disso, partimos do pressuposto de que os materiais audiovisuais constituem excelente ferramenta para a prática de sala de aula no âmbito de uma abordagem intercultural, tendo em vista que filmes e seriados, por exemplo, relatam aspectos socioculturais, linguísticos, históricos e políticos (STEFANI 2010; MARQUES E ROZENFELD 2017). A partir deles, é possível ao professor incitar discussões e propor atividades e pesquisas com os seus alunos sobre a língua/cultura-alvo.

No entanto, é importante considerar o risco de materiais desse tipo, caso não sejam criticamente analisados pelo professor e pelo aluno, propagarem ou contribuírem para a difusão da ideia de que o falante nativo é o guardião daquela língua (RAJAGOPALAN 2012) e que, portanto, ele consiste no único modelo de aprendizagem. Isso pode ocorrer, por exemplo, por meio da retratação pejorativa ou cômica do estrangeiro, visto como alguém incapaz de atingir os seus objetivos comunicacionais e que gera inúmeras situações constrangedoras, restando ao falante nativo resolvê-las. Acreditamos que, para o aluno, um falante intercultural em desenvolvimento, tal imagem do estrangeiro possa acarretar consequências negativas, como a baixa autoestima para atuar na LE, podendo chegar à desmotivação para dar continuidade ao estudo da língua. 
Crespo, A.H.; Rozenfeld, C. - Protagonistas de séries voltadas para a aprendizagem de alemão

Considerando que o falante intercultural é também um bom exemplo de aprendizagem, em consonância com House (2007), pretendemos neste trabalho analisar a forma como são retratadas as protagonistas estrangeiras de dois seriados produzidos por importantes difusores da língua alemã para o ensino e aprendizagem do idioma, a saber: Erste Wege in Deutschland, série criada pelo Goethe Institut, e Jojo sucht das Glück, também um seriado online, mas da organização de radiodifusão alemã Deutsche Welle. Assim, interessa-nos verificar se essas séries, transmitidas por fontes de renome no campo do alemão como LE, reproduzem a concepção de falantes interculturais (mais ou menos) estáveis, conforme a concepção de House (2007).

Justificamos a escolha dos seriados analisados por dois motivos: primeiramente, as falantes interculturais assumem um papel central na trama, tornando-se foco de maior atenção do espectador/aluno de LE. Em segundo lugar, devido à inegável relevância, tanto do Goethe Institut quanto do jornal alemão Deutsche Welle, para a divulgação da língua e cultura alemã pelo mundo. ${ }^{3}$ Ambas instituições têm grande influência sobre o contexto do ensino e da aprendizagem de alemão, sobretudo no que diz respeito à aprendizagem autônoma dos alunos, os quais podem encontrar uma ampla oferta de materiais didáticos disponibilizados nas plataformas online do instituto e da empresa supracitados. Por isso, partimos do pressuposto de que esses seriados sejam, não só comumente usados por professores de alemão em sala de aula, como também por aprendizes (e demais interessados em aprender alemão) fora do contexto escolar, fato que denota uma relevância dessas duas produções para a área.

\section{Pressupostos teóricos}

Nesta seção serão discutidas, primeiramente, as qualidades dos materiais audiovisuais para o processo de ensino e aprendizagem. Em segundo lugar, abordaremos o tratamento dado a componentes culturais por métodos e abordagens de ensino, o papel do falante nativo no ensino de LE e, por último, traçaremos algumas características do falante intercultural, com base em autores que já dissertaram sobre o assunto.

\footnotetext{
${ }^{3}$ Conforme a página oficial do Goethe Institut (<https://www.goethe.de/de/wwt.html〉), há até a presente data, 159 institutos distribuídos em todos os seis continentes, totalizando 98 países. Também em sua página oficial (<http://www.dw.com/de/unternehmen/profil/s-30626>), a Deutsche Welle afirma ter, semanalmente como público, mais de 157 milhões de pessoas em todo o globo.
} 
Crespo, A.H.; Rozenfeld, C. - Protagonistas de séries voltadas para a aprendizagem de alemão

\section{1 $\bigcirc$ uso de materiais audiovisuais como recurso didático}

O cinema é um recurso, por meio do qual podemos vislumbrar outras realidades e ampliar a nossa visão de mundo (CRUZ; SouZA; GAMA 2007). Assim, diante dessa sua potencialidade para despertar novos olhares em seus espectadores e propagar conhecimentos, o cinema logo foi percebido como um possível (e rico) material didático (ARAUJO; Voss 2009), tornando-se, hoje, cada vez mais utilizado em sala de aula, devido à maior praticidade e disponibilidade que as novas tecnologias, como a internet e o computador, lhe conferiram (PIRES 2011).

Sob essa perspectiva, é importante destacar as características positivas dos materiais audiovisuais (doravante MA) para o ensino e aprendizagem de língua estrangeira, tais como o fato de tratar-se de material inovador e multimodal, que possibilita o trabalho inter e transdisciplinar, interações autênticas na sala de aula e facilita o desenvolvimento de estratégias de compreensão (CRUZ, SOUZA E GAMA 2007; STEFANI 2010; PIRES 2011; MARQUES E RozENFELD 2017). É importante evidenciar, ainda, o caráter lúdico dos MA, o que justifica o fato de serem um dos meios favoritos de entretenimento. Por isso, é imprescindível que o professor se aproveite das vantagens desse material para despertar, em seus alunos, o interesse pelo conteúdo programado, bem como para gerar um ambiente propício para a aprendizagem (MORÁN 1995; STEFANI 2010; MARQUES E ROZENFELD 2017).

Assim, sustentamos que os MA (dentre os quais incluímos filmes de diferente natureza, como séries televisivas, vídeos em redes sociais como o "Youtube", etc, e não apenas os da sétima arte) são capazes de promover o interesse dos alunos, quando usados adequadamente e bem selecionados, pois, concordando com Morán (1995), esse tipo de recurso foge da tradicional linguagem da escola regular, ${ }^{4}$ a qual é, muitas vezes, pautada apenas na linguagem verbal (oral e escrita), desconsiderando, assim, as linguagens visuais, gestuais, sonoras etc.

\footnotetext{
${ }^{4}$ Embora reconheçamos que a realidade do ensino de alemão como língua estrangeira não seja a mesma do ensino regular no Brasil (dado o número de alunos que aprendem a língua, a infraestrutura dos institutos de idioma, os avanços didáticos na área de ALE e outros fatores), parece-nos problemático pressupor que não haja contextos de ensino de ALE semelhantes às práticas encontradas no ensino regular, sobretudo no que diz respeito à predominância da linguagem verbal. Por isso, julgamos ser pertinente para a área tecer reflexões acerca do tratamento de diversas linguagens por meio dos materiais audiovisuais.
} 
Crespo, A.H.; Rozenfeld, C. - Protagonistas de séries voltadas para a aprendizagem de alemão

Em consonância com Morán (1995), Stefani (2010) defende que a presença de diferentes linguagens nos MA contribui para que o aluno compreenda melhor o insumo, uma vez que não só o verbal, mas também o gestual, o visual e o sonoro auxiliam na emissão da mensagem pretendida. Ademais, a autora alerta para o fato de que a linguagem verbal compreende apenas $7 \%$ dentre todas as nossas formas de comunicação. Tomando isso como base, podemos constatar que escolas que utilizam somente a linguagem verbal para o ensino de uma LE não preparam satisfatoriamente o aluno para as situações reais de fala.

Na esteira dessa discussão, Rojo (2012) defende o ensino baseado nos multiletramentos, considerando-se que, na era da revolução digital em que vivemos, os textos adquirem as mais variadas materialidades, sendo compostos por sons, vídeos, imagens, etc. Dessa forma, é essencial que os alunos sejam preparados para se comunicar de acordo com o que é exigido na realidade atual e não conforme os padrões de textos somente verbais que outrora predominavam.

Partindo da premissa de que a adoção de recursos audiovisuais prevê o trabalho com múltiplas linguagens, não podemos nos esquecer da possibilidade de o professor propor atividades mediadas por TDICs (Tecnologias Digitais de Informação e Comunicação), aliadas à exibição de filmes (STEFANi 2010) ou de seriados (MARQUES; ROZENFELD 2017).

Muito tem se apontado acerca dos benefícios do uso de TDICs para o ensino e aprendizagem de LE (BAX 2003; LEFFA 2006; SANCHO 2006; PAIVA 2015). Seguindo essa lógica, Stefani (2010) relata o sucesso do uso do cinema em aulas, nas quais foram realizadas atividades de pesquisa na internet e por meio de celulares, possibilitando a participação também de alunos que não puderam estar presentes em sala de aula, e o fizeram a distância.

Diante do exposto, defendemos que o professor, ao promover atividades mediadas por essas mídias, contribui para o desenvolvimento da autonomia de seus alunos, os quais terão que, conforme a proposta da atividade, investigar, refletir e solucionar dado problema de forma autônoma, como já apontado por Rozenfeld e Marques-Schäfer (2017). Acerca dessa postura ativa dos alunos diante de atividades com TDICs, Stefani (2010) sustenta que o cinema também pode ser utilizado para o mesmo propósito, desenvolvendo, portanto, a autonomia do aluno. Segundo a autora, isso ocorre quando os aprendizes são incitados, por meio de atividades propostas pelo professor, a interagir entre 
Crespo, A.H.; Rozenfeld, C. - Protagonistas de séries voltadas para a aprendizagem de alemão

si, negociando sentidos e atribuindo significados referentes ao material audiovisual exibido.

Outra característica positiva dos MA para o ensino e aprendizagem de língua estrangeira diz respeito à motivação que eles suscitam nos alunos, posto que são materiais autênticos, não muito corriqueiros em sala de aula e aproximam o aluno da língua e cultura-alvo por abordar seus aspectos socioculturais (DÖRNYEI 1994; CRUZ; SOUZA; Gama 2007; Stefani 2010; Marques e Rozenfeld 2017). Consoante a isso, Dörnyei (1994) recomenda que o professor de LE utilize filmes, seriados de TV e música em suas aulas, porque, além de eles elevarem a motivação dos alunos, podem, assim, suscitar discussões sobre traços positivos e relevantes da língua/cultura-alvo.

Dörnyei (1994) destaca, ainda, o efeito motivador de materiais autênticos para o ensino de línguas, dado que eles tornam o curso mais atrativo. Tendo em vista que os MA podem ser enquadrados nessa categoria, como observado pelos autores acima, também reconhecemos que há uma grande variedade de materiais audiovisuais, muito embora nem todos se encaixam na concepção de material autêntico. Por essa razão, nos parece essencial buscar uma definição sobre autenticidade, a fim de melhor compreendermos o material que focalizamos neste trabalho.

Para Carvalho (1993), o material autêntico trata-se de um produto destinado a um público comum da comunidade linguística em questão e que não passou por um processo de adaptação ou simplificação para atender as especificidades de alunos da LE. Como exemplo desse tipo de material, a autora cita jornais, filmes, discos, revistas, programas de TV, livros, entre outros. Aliado à definição de Carvalho (1993), Berardo (2006) acrescenta que materiais autênticos são produzidos para falantes nativos e que o uso dos não-autênticos no ensino serve, por um lado, para a aprendizagem de estruturas gramaticais, mas, por outro, não auxilia o aluno no desenvolvimento das competências necessárias para as situações reais de comunicação, dada a artificialidade desse tipo de material. Devemos salientar que, contrariamente ao autor, defendemos que materiais autênticos são produzidos, não apenas para falantes nativos, mas também para os inúmeros falantes não-nativos que residem na cultura estrangeira e usufruem de materiais autênticos na LE de forma bem-sucedida. Assim, sustentamos que o cerne da definição está na finalidade de produção do material e não no tipo de receptor/leitor.

Alinhada a essa ideia, Andrade e Silva (2017) apresenta subdivisões na definição de material autêntico. Embora a discussão levantada pelos autores seja mais direcionada 
Crespo, A.H.; Rozenfeld, C. - Protagonistas de séries voltadas para a aprendizagem de alemão

para textos, acreditamos que os seus apontamentos possam ser ampliados para os materiais audiovisuais. A autora postula que os materiais didáticos podem ser subdivididos em autênticos, autênticos adaptados, semi-autênticos e não-autênticos. Isso significa que, tanto os autênticos quanto os autênticos adaptados, foram originalmente criados sem qualquer finalidade pedagógica, porém, o segundo sofreu uma adaptação, de modo a poder ser melhor empregado em sala de aula, conforme os objetivos e o públicoalvo. O material semi-autêntico, por sua vez, foi elaborado desde o início com o propósito de ser material didático, contudo, diferentemente do não-autêntico, ele possui características que o tornam muito semelhante ao material autêntico. Muito embora a autora argumente que o trabalho com textos autênticos seja importante, pois por meio deles os alunos podem tanto desenvolver estratégias de compreensão quanto se envolver com o conteúdo e seus aspectos socioculturais, ela chama a atenção para o fato de que a tipologia mencionada acima não foi pensada a partir de uma hierarquização, posto que cada tipo de material pode cumprir um propósito pedagógico a que foi destinado.

Concordamos com Andrade e Silva (2017) em relação à não hierarquização desse tipo de material e defendemos o potencial dos materiais autêntico, autêntico adaptado e semi-autêntico, pois por meio deles é possível uma maior aproximação dos alunos com a cultura e língua-alvo, que, no caso da aprendizagem de alemão, como destacam Marques e Rozenfeld (2017), é de suma importância, tendo em vista que a maioria dos alunos tem pouco contato com a cultura alemã fora do contexto de ensino.

Embora não faça parte do escopo deste trabalho uma análise mais aprofundada sobre as séries em foco quanto a sua autenticidade, julgamos que tais reflexões sejam pertinentes para compreendermos melhor as condições de produção do material, fato que pode impactar na análise dos protagonistas, conforme nos propomos a fazer.

Destaca-se, ainda que o cinema é o recurso que melhor exerce a função de aproximar o aprendiz da realidade estudada, uma vez que ele possibilita ao aluno "não só o contato com elementos linguísticos, mas também com elementos pragmáticos e socioculturais colocados em contexto" (PIRES 2011: 09). Desse modo, ao aproximar o aluno da cultura e língua-alvo, o MA pode contribuir para o processo de desestranhamento desse aprendiz (ROZENFELD E VIANA 2011).

Conforme Rozenfeld e Viana (2011), o estranhamento sobre uma língua e cultura pode ter consequências positivas ou negativas para o aluno: se por um lado o aprendiz 
Crespo, A.H.; Rozenfeld, C. - Protagonistas de séries voltadas para a aprendizagem de alemão

pode se sentir motivado a desvendar e compreender aquilo que lhe é estranho, por outro, pode emergir um muro entre ele e a aprendizagem da língua/cultura.

Ainda sobre a importância do desestranhamento, os autores sustentam que, além de poder reduzir (ou extinguir) o bloqueio do aluno para aprender a língua estrangeira, ele pode estimular que o aprendiz adquira conhecimento sobre as suas próprias crenças e percepções, sendo isso indispensável para o desenvolvimento da competência intercultural, como apontado por Byram, Gribkova e Starkey (2002) na seção seguinte. Assim, Rozenfeld e Viana (2011) afirmam considerar "o desestranhamento do estranho como objetivo central do ensino intercultural: a desconstrução da interpretação que distancia a compreensão do outro" (ROZENFELD; VIANA 2011: 264).

Por fim, argumentando ainda em favor do uso de MA para o processo de desestranhamento e aproximação entre as culturas, Stefani (2010) advoga que o aluno, ao estar em contato com a cultura-alvo por meio desses recursos, passa por um processo de adaptação que pode facilitar o seu convívio futuro com o outro, posto que, consciente das formas de interação e dos costumes da cultura-alvo, o aprendiz passa a se sentir mais confiante para se comunicar na língua aprendida.

É importante enfatizar, porém, que as potencialidades didático-pedagógicas dos MA apresentadas anteriormente só poderão ser concretizadas se o professor tiver claros seus objetivos de ensino e os critérios de planejamento da aula, na qual tal material é inserido. Tal fato é destacado também por Stefani (2010: 63), que sustenta que "a abordagem do professor é essencial quando nos referimos ao trabalho com filme na aula de LE. É ela que vai permitir que o objetivo primordial de promover atividades significativas, interativas e comunicativas seja atingido".

Morán (1995) aponta que o professor deve evitar fazer uso do MA apenas quando ocorre algum imprevisto com o planejamento da aula (por exemplo, passar um filme sem um objetivo didático específico, apenas para suprir uma falta do professor, ou algum problema de organização da escola), porque, com o tempo, isso sedimentará a crença dos alunos de que os MA se tratam apenas de "cartas na manga" do professor ou da instituição. Além disso, o autor critica o uso de MA de modo descontextualizado com a matéria, sem nenhuma discussão ou proposta de pesquisa após a exibição, e o seu uso exagerado, provocando cansaço nos alunos e negligenciando outros tipos de atividade. 
Crespo, A.H.; Rozenfeld, C. - Protagonistas de séries voltadas para a aprendizagem de alemão

Concordamos com Morán (1995) e, por isso, defendemos que o uso de MA no ensino e aprendizagem de LE seja feito de forma criteriosa, crítica e planejada, de modo que o MA acrescente positivamente na prática do professor e auxilie no alcance dos objetivos pedagógicos, contribuindo, assim, para um processo de aprendizagem mais satisfatório.

Diante do exposto, devemos destacar que reconhecemos a potencialidade pedagógica dos seriados analisados, uma vez que se caracterizam como MA e reiteramos a relevância de se refletir sobre o papel do falante intercultural, visto que este aspecto poderá impactar na aprendizagem do aluno, em sua formação como cidadão, no desenvolvimento de sua autonomia, no processo de desestranhamento e no trabalho com diferentes linguagens, que não só a verbal.

Assim, apresentamos no item a seguir as reflexões sobre os conceitos de falante intercultural, iniciando, porém, com uma reflexão sobre o ensino de cultura em sala de aula de LE.

\subsection{A cultura no ensino de língua estrangeira, o falante nativo ideal e o falante intercultural mais (ou menos) estável}

Definir cultura é notadamente uma tarefa complexa. Desde a sua origem para designar o “cultivo da terra" (Dourado; Poshar 2010: 35), o termo já sofreu diversas ressignificações, cada qual em conformidade com a ideologia vigente da época. Como Bauman (2013) relata, a cultura já desempenhou, entre outras mais, a função de (1) distinguir os sujeitos por classe social de acordo com os produtos culturais que consumiam, (2) alterar, como ferramenta de instrução, o status quo de membros de grupos sociais cujo conhecimento cultural era desprestigiado, (3) colonizar povos por meio da justificativa da difusão de um suposto conhecimento verdadeiro e (4) proteger "o Estadonação de ventos e correntes cambiantes" (BAUMAN 2013: 15), recorrendo à tentativa de unificação cultural de diferentes povos que foram agrupados em um mesmo território.

Segundo o filósofo, nos dias de hoje a cultura serve aos interesses do estilo de vida $^{5}$ contemporâneo, baseado no fluxo intenso de oferta e procura do mercado. Em outras

\footnotetext{
5 Bauman (2013) denomina a época em que vivemos de modernidade líquida, posto que "o que torna 'líquida' a modernidade, e assim justifica a escolha de seu nome, é a 'sua modernização' compulsiva e obsessiva, capaz de impulsionar e intensificar a si mesma, em consequência do que, como ocorre com os 
Crespo, A.H.; Rozenfeld, C. - Protagonistas de séries voltadas para a aprendizagem de alemão

palavras, a função atual da cultura, de acordo com Bauman (2013), é gerar produtos para consumo, os quais já sabidamente terão uma expectativa de vida muito curta em decorrência da rápida chegada de produtos mais novos e melhorados. Nós, indivíduos dessa época, mantemos esse ciclo vicioso na tentativa de nos alienarmos do sentido da vida (BAUMAN 2013).

Essa diversidade de olhares sobre o conceito de cultura também está presente na Antropologia. Se antes os antropólogos investigavam as culturas por um viés essencialista, ou seja, partindo do pressuposto de que cada povo detinha características típicas que eram comuns a todos os seus membros, hoje em dia acredita-se que a cultura é um fenômeno dinâmico, capaz de mudar conforme as necessidades da época e por meio do contato com outras culturas e povos (DERVIN 2014).

É no âmbito dessa última perspectiva que se enquadra a nossa visão de cultura, e que predomina nas metodologias de ensino e aprendizagem de LE a partir da década de oitenta do século passado, a partir das abordagens multicultural e intercultural (SALOMÃO, 2015). Todavia, devemos enfatizar que o propósito deste trabalho não está em nos aprofundar na discussão sobre o conceito, mas gerar reflexões para o ensino com cultura (OLIVEIRA 2012: 86). Isto é, as nossas considerações estão direcionadas para educadores que, em suas aulas, utilizam (ou desejam utilizar) componentes culturais como ferramentas para se atingir um determinado objetivo didático-pedagógico, em nosso caso, o de ensino de alemão como língua estrangeira.

Tendo isso em vista, o nosso enfoque recai na abordagem de aspectos culturais em sala de aula.

Kramsch (2011) afirma que na época do surgimento da Linguística Aplicada (doravante LA), nas décadas de 1940 e 1950, a cultura ainda era domínio da Literatura (na qual, conforme o conceito de Cultura com $\mathrm{C}$ maiúsculo, apenas produtos culturais de prestígio, como a arte, eram considerados) e da Antropologia (que abarcava, por sua vez, também as crenças, os costumes e os valores de um povo como manifestações culturais, o que passou a ser conhecido como concepção de cultura com c minúsculo). A cultura, segundo a autora, passou a ser objeto de estudo da LA quando esta voltou a sua atenção para o discurso, visto que considerar a língua como um processo discursivo significava

líquidos, nenhuma das formas consecutivas da vida social é capaz de manter o seu aspecto por muito tempo" (BAUMAN 2013: 16). 
Crespo, A.H.; Rozenfeld, C. - Protagonistas de séries voltadas para a aprendizagem de alemão

reconhecer também os seus elementos contextuais e históricos. Isso pode ser verificado quando a autora afirma que:

O fato de a linguística aplicada ser uma ciência aplicada confrontou os seus pesquisadores com a necessidade de levar em consideração o contexto social e histórico da língua em uso. [...] Portanto, além do sistema linguístico padrão, a cultura tornou necessário o estudo sobre a variação linguística e estilística, as comunidades discursivas situadas social e historicamente, os diferentes modos de exercer o poder simbólico e as lutas por reconhecimento e legitimação cultural (KRAMSCH 2011: 306, tradução nossa). ${ }^{6}$

Nesse sentido, com a inserção da cultura como foco de investigação da LA, a forma como os aspectos culturais eram tratados pelos métodos e abordagens ${ }^{7}$ de ensino de LE começou a ser reconsiderada. No método Gramática e Tradução, por exemplo, entendia-se que o aluno aprenderia a cultura-alvo por meio da leitura de seus cânones, posto que eles, considerados produtos da inteligência e da criatividade humana, representavam a cultura daquela comunidade (NEUNER; HUNFELD 1993; TAVARES 2006).

Em seguida à Gramática e Tradução, muito criticada por se valer do mesmo método de ensino de línguas clássicas (como Latim e Grego antigo) para ensinar línguas modernas, surge o Método Direto, cujo foco deixa de ser a leitura de clássicos da Literatura e se torna a aprendizagem de situações reais do dia a dia da língua e culturaalvo (NEUNER; HunFELD 1993). Dessa forma, os autores apontam que, nesse método, o ensino de Landeskunde ${ }^{8}$ se deu por meio de materiais que conduziam a temáticas do cotidiano, tais como o próprio livro didático ou mesmo contos de fada, canções, rimas, entre outros, abandonando-se, assim, grandes obras da Literatura.

Podemos observar, portanto, uma mudança da concepção de cultura na transição da Gramática e Tradução para o Método Direto, a qual perdurou, posteriormente, no método Áudio-lingual e na abordagem comunicativa (NEUNER; HUNFELD 1993; TAVARES 2006; STANKE 2014). Em outras palavras, houve um afastamento do conceito de Cultura

\footnotetext{
${ }^{6}$ No original: "The fact that applied linguistics was an applied science confronted its researchers with the need to take into account the social and historical context of language in use. [...] Thus, beyond the standard linguistic system, culture made it necessary to study linguistic and stylistic variation, socially and historically situated discourse communities, different ways of exercising symbolic power, and struggles for cultural recognition and legitimation."

${ }^{7}$ Adiante neste trabalho, abordaremos os métodos Gramática e Tradução, Método Direto e Áudio-lingual e a abordagem comunicativa, tomando como base a distinção feita por Vieira-Abrahão (2015), segundo a qual o método prescreve formas de ensino, enquanto a abordagem confere ao professor maior liberdade para exercer a sua prática conforme o seu contexto de sala de aula e as necessidades de seus alunos.

${ }^{8}$ Conforme Stanke (2014), o termo alemão Landeskunde, junção das palavras Land (país) e Kunde (ciência), denota o conhecimento sobre as crenças, os costumes, os fatos, entre outros aspectos de um povo.
} 
Crespo, A.H.; Rozenfeld, C. - Protagonistas de séries voltadas para a aprendizagem de alemão

com C maiúsculo, dominante na GT, e uma consequente aproximação do de cultura com c minúsculo.

Essa mudança de paradigma, por um lado, significou compreender a cultura de uma maneira mais ampla e com um olhar menos elitista, mas, por outro lado, adotou-se um viés essencialista, dado que, como relata Kramsch (2011), as manifestações culturais eram vistas como uniformes à toda comunidade-alvo, desconsiderando-se as peculiaridades regionais, de cada grupo social e mesmo individuais.

Tavares (2006) critica a forma como essa concepção de cultura foi adotada no ensino, destacando que, na abordagem comunicativa, os alunos eram estimulados a imitar os hábitos dos membros da cultura-alvo. Como consequência, a autora aponta que a individualidade dos aprendizes era desconsiderada e que não havia espaço para a reflexão sobre os aspectos da própria cultura e da cultura-alvo. Seguindo essa lógica, Busnardo (2010) argumenta que, embora a concepção de competência comunicativa tenha, em seu surgimento, aberto caminho para novas discussões sobre cultura, ela concebia somente o elemento sociolinguístico da comunicação, esquecendo-se de seu caráter pragmáticodiscursivo. Dessa forma, a criatividade do falante para gerar discursos era ignorada e o aluno via-se em uma "camisa de força que não permitia a emergência de sujeitos discursivos, ativos e críticos" (BUSNARDO 2010: 124).

À medida que o pensamento pós-moderno ganhava força, com base no qual a cultura começou a ser vista como um fenômeno dinâmico e que foge da concepção engessada que lhe foi atribuída até então, a ideia de que padrões comportamentais devem ser ensinados e reproduzidos começou a ser criticada e abandonada pelas abordagens (BUSNARDO 2010). A autora afirma que

Para a pós-modernidade, existem múltiplas culturas em cada país, e cada uma está em fluxo. O estático é substituído pelo dinâmico; a "camisa de força" pelo "verbo". São colocadas em questão, sobretudo, noções de "cultura nacional"; as identidades são múltiplas - de etnia, gênero, religião, grupo profissional, etc - e os que se opõem a tal visão são acusados de "essencialismo cultural" (BUSNARDO 2010: 130).

Em virtude dessa mudança de pensamento e sob a influência de movimentos que lutavam pelo reconhecimento de grupos minoritários, Salomão (2015) relata a emergência, nos anos 1980, da abordagem multicultural, a qual propunha que as diversidades culturais e linguísticas presentes em uma comunidade fossem também consideradas no ensino, em contraposição à ideia de valorização apenas da cultura padrão. 
Crespo, A.H.; Rozenfeld, C. - Protagonistas de séries voltadas para a aprendizagem de alemão

Surgida nessa mesma época, a abordagem intercultural contribuiu, como sustenta Stanke (2014), para que o ensino de Landeskunde se voltasse para o entendimento sobre a própria cultura além da cultura-alvo. Dessa forma, segundo a autora, comparações entre C1 e C2 adquiriram o intuito de gerar um olhar sensível no aluno acerca das semelhanças e diferenças entre ambas. Nesse sentido, Neuner e Hunfeld (1993), em capítulo sobre as premissas da abordagem intercultural, afirmam ser de suma importância considerar a visão de mundo e a experiência de vida do aluno ao se tratar sobre temas relativos à cultura-alvo, de modo que essa nova descoberta se torne interessante para ele e não um choque cultural.

Com essa virada intercultural no campo de ensino e de aprendizagem de LE, cujo olhar se voltou para as diversidades, o conceito de falante nativo como modelo de aprendizagem foi colocado em discussão (KRAMSCH 1998). Para a autora, o falante nativo, como é comumente concebido, não é apenas um sujeito que, desde o seu nascimento, obedece a padrões linguísticos, mas também aquele que possui características físicas tidas como típicas aos membros daquela cultura.

Para exemplificar o que Kramsch (1998) postula, citamos o vídeo "Shit some white Germans say to black Germans" do canal Sidneyvlog. ${ }^{9}$ Nesse vídeo, o vlogger relata que, embora seja alemão, muitos alemães brancos o questionam sobre a sua nacionalidade ou elogiam a sua fluência e domínio da língua apenas pelo fato de ele ser negro. Isto é, na visão de muitos alemães, o uso da língua conforme os padrões estipulados para falantes nativos não foi suficiente para, à primeira vista, conferir ao vlogger a identidade de alemão, visto que ele não apresenta determinadas características físicas, tais como pele branca, cabelo loiro e olhos claros.

Acerca disso, Kramsch (1998) pontua que

O falante nativo é [...] uma abstração monolingual e monocultural; ele/a é aquele/a que fala apenas a sua língua nativa (padronizada) e vive em uma cultura nacional (padronizada). Na realidade, a maioria das pessoas partilham de várias línguas ou variedades linguísticas e vivenciam várias culturas ou subculturas (KRAMSCH 1998: 80, tradução nossa). ${ }^{10}$

\footnotetext{
${ }^{9}$ A nossa tradução para o título é "m*rdas que alguns alemães brancos dizem para alemães negros" e ele pode ser acessado sob o link: <https://www.youtube.com/watch?v=63h0vwUT-vY>. Acesso em: 28 abr. 2018.

${ }^{10}$ No original: "The native speaker is, moreover, a monolingual, monocultural abstraction; he/she is one who speaks only his/her (standardized) native tongue and lives by one (standardized) national culture. In 
Crespo, A.H.; Rozenfeld, C. - Protagonistas de séries voltadas para a aprendizagem de alemão

Em consonância com a autora, Rajagopalan (2012) defende que o conceito de falante nativo, assim como o da língua como uma entidade uniforme, é um mito. Segundo o pesquisador, o que observamos, por meio da interação entre as pessoas, são "certos vocábulos em determinados jeitos" ${ }^{11}$ (RAJAGOPALAN 2012: 40, tradução nossa), mas afirmar que existem línguas sólidas, de modo análogo a entidades, como se acredita existir uma língua espanhola, alemã, inglesa, etc., é muito questionável, pois não se tem nenhum respaldo científico que ratifique tal ideia. Entretanto, dado que, por meio desse mito, a língua se constitui como um objeto de estudo bem definido (o que é vantajoso para os linguistas), o autor sustenta que pouco se tem avançado em direção à sua desmistificação, cabendo ao falante nativo desempenhar o papel de guardião dessa entidade linguística (RAJAGOPALAN 2012). Com essa proposição, nota-se que cai por terra a crença do falante nativo como um representante da língua, ao considerarmos que não existe uma entidade linguística, a qual pode ser tida como exemplar de uma cultura.

Em relação à origem do termo, Rajagopalan (2012) relata que a palavra "nativo" foi primeiramente empregada pelos colonizadores europeus para designar de forma pejorativa os habitantes das terras conquistadas. Na linguística, o conceito que conhecemos de falante nativo ganhou força com o gerativismo de Chomsky, para quem esse falante, graças à sua intuição linguística, trata-se do único responsável por fornecer dados fidedignos sobre a língua investigada (cf. RAJAGOPALAN 2012). Com isso, o pesquisador sustenta que os falantes nativos passaram a ser vistos como os únicos falantes verdadeiros da língua. ${ }^{12}$

Nesse sentido, o falante nativo tornou-se um modelo a ser seguido pelos aprendizes de língua estrangeira, o que causava (e acreditamos que na grande maioria das escolas de idioma ainda cause) uma frustração nos alunos, que viam nessa missão um objetivo inalcançável (BUSNARDO 2010). Ao ser posto em xeque o conceito de falante nativo, autores passaram a advogar a concepção do falante intercultural e o

reality, most people partake of various languages or language varieties and live by various cultures and subcultures."

11 "certain vocables in determine ways".

12 No caso da língua inglesa, os seus falantes nativos tornaram-se celebridades adoradas por escolas de idiomas, as quais muitas vezes se aproveitam dessa crença e usam como propaganda o fato de terem professores nativos da língua, provocando que professores não nativos sejam preteridos pelos próprios alunos, como apontado por Rodrigues (2016). 
Crespo, A.H.; Rozenfeld, C. - Protagonistas de séries voltadas para a aprendizagem de alemão

desenvolvimento da competência de comunicação intercultural no ensino de línguas (BYRAM; GRIBKOVA; STARKEY 2002; HOUSE 2007; OLIVEIRA 2012).

Ao destituir o falante nativo do papel de modelo de aprendizagem, House (2007) sustenta que falantes interculturais mais estáveis devem servir como exemplos para falantes interculturais menos estáveis, dado que ambos possuem em comum a bi-, tri- ou multiculturalidade, diferentemente do falante nativo ideal, que se trata de um indivíduo monocultural. Em outras palavras, os aprendizes de língua estrangeira abandonariam a tentativa frustrante de se espelhar no estereótipo do membro da cultura-alvo e passariam a se reconhecer em falantes que, assim como eles, vivenciam cultura(s) estrangeira(s), mas que detêm a competência de comunicação intercultural, mais desenvolvida do que os aprendizes em questão.

Tendo isso em vista, a autora define falante intercultural como "[...] uma pessoa que conseguiu se estabelecer no intermediário, que sabe e consegue performar tanto em sua cultura nativa quanto em uma outra adquirida em um momento depois". (HousE 2007: 19, tradução nossa). ${ }^{13}$ Ademais, falantes interculturais seriam indivíduos híbridos, no sentido de que possuem traços e influências de mais de uma cultura, o que pode ser manifestado fenotipicamente, por meio de interferências linguísticas, e/ou genotipicamente, tratando-se das visões de mundo e perspectivas das culturas envolvidas (cf. HOUSE 2007).

A autora argumenta que o falante intercultural deve ser reconhecido como alguém em vantagem comunicativa, posto que ele, por ter como arsenal de conhecimento mais de uma cultura e língua, dispõe de um grande leque de recursos discursivos, dos quais ele pode lançar mão para atingir os seus objetivos comunicacionais, conferindo ao seu discurso identidade, comicidade, polidez e outros efeitos intencionais. Nesse sentido, a autora salienta que os assim denominados "desvios da norma", quando deliberadamente realizados, devem deixar de ser vistos como amostra da ignorância do falante intercultural. Em vez disso, deve-se considerá-los como demonstração da competência desse falante, que está fazendo uso de estratégias discursivas com propósitos comunicativos.

\footnotetext{
${ }^{13}$ No original: "a person who has managed to settle for the In-between, who knows and can perform in both his and her native culture and in another one acquired at some later date."
} 
Crespo, A.H.; Rozenfeld, C. - Protagonistas de séries voltadas para a aprendizagem de alemão

Considerando o falante intercultural como modelo de aprendizagem, o desenvolvimento da competência intercultural (doravante $\mathrm{CI}$ ) torna-se um requisito para o aluno de línguas estrangeiras. Na esteira dessa discussão, Byram, Gribkova e Starkey (2002) postulam que o desenvolvimento da CI pressupõe a aprendizagem de determinados conhecimentos, habilidades, atitudes e valores.

Por atitudes (ou savoir être), os autores referem-se à capacidade do indivíduo de descentralizar as suas crenças e perspectivas, tendo consciência de que não há uma hierarquia entre as crenças e valores de diferentes grupos. Além disso, o falante/mediador intercultural deve ter uma postura de curiosidade e receptividade diante do outro.

No que diz respeito aos conhecimentos (savoirs), Byram, Gribkova e Starkey (2002) argumentam que o falante/mediador intercultural deve conhecer os produtos e as práticas pertencentes à cultura-alvo, o que inclui a noção que os membros dessa cultura têm de você e de outras culturas. Reconhecemos a importância desses conhecimentos, de modo que mal-entendidos possam ser evitados e que o falante intercultural saiba a quais estratégias comunicativas recorrer para atingir determinado objetivo, porém salientamos a importância de se ter sempre em mente que nem todos os membros dessa cultura se comportarão conforme dadas práticas e terão familiaridade com certos produtos.

Quanto às habilidades (savoir comprendre), Byram, Gribkova e Starkey (2002) defendem que o falante/mediador intercultural deve ser capaz de se colocar no lugar do outro, assim como ter ciência de sua própria visão de mundo, prevendo e evitando malentendidos. Uma outra habilidade (savoir aprendre/faire) defendida pelos autores é a de saber adquirir novos conhecimentos sobre a cultura-alvo por meio da interação, seja perguntando diretamente ou observando os membros dessa cultura, e aplicar esse conhecimento nas suas próximas interações futuras.

Por fim, em relação aos valores (savoir s'engager), Byram, Gribkova e Starkey (2002) destacam que, por mais que acreditemos estar totalmente abertos para a diversidade, os nossos valores sempre se manifestarão e nunca de uma forma neutra, por isso é de suma importância que desenvolvamos a capacidade de ter consciência sobre os nossos próprios valores e como isso repercute na nossa visão acerca dos valores, crenças e costumes do outro.

Em consonância com as ideias relatadas acima, Oliveira (2012) aponta algumas habilidades a serem desenvolvidas pelos aprendizes no que se refere ao desenvolvimento 
Crespo, A.H.; Rozenfeld, C. - Protagonistas de séries voltadas para a aprendizagem de alemão

da competência comunicativa intercultural, sendo elas: ser capaz de a) mediar interações entre membros de diferentes culturas, b) aceitar diferentes perspectivas que não só a sua, c) enxergar a realidade por meio de outras lentes e d) reconhecer a tendência a achar a sua própria cultura melhor que a outra. Dessa maneira, podemos observar um enfoque muito maior sobre o encontro intercultural, abarcando as suas consequências - como, por exemplo, o choque de perspectivas -, e um certo afastamento da concepção que atribuía aos aspectos linguísticos um papel central nos estudos de LE.

Acerca da função do professor perante essa tarefa de desenvolver em seus alunos a competência comunicativa intercultural, tanto Oliveira (2012) quanto Byram, Gribkova e Starkey (2002) sustentam o seu dever de proporcionar condições favoráveis para que as habilidades supracitadas sejam aprendidas e desenvolvidas pelos alunos. Assim sendo, pouco importa a nacionalidade ou a L1 desse professor.

Com base nos apontamentos feitos por Byram, Gribkova e Starkey (2002), House (2007) e Oliveira (2012), concluímos que o falante intercultural mais estável, que pode servir como modelo de aprendizagem, possui as seguintes características:

- encontra-se entre duas ou mais culturas/línguas, sendo capaz de interagir e se posicionar em todas elas;

- é um indivíduo híbrido, ou seja, que carrega traços das culturas, das quais faz parte; desse modo, esse falante não se transforma em um membro ideal da cultura estrangeira, visto que ele, por um lado, não perde a sua antiga identidade e, por outro, adquire novos traços provenientes do contato com a nova cultura;

- faz uso estratégico e deliberado de recursos discursivos (como, por exemplo, interferências da L1 na L2) para atingir um determinado objetivo comunicativo;

- tem interesse em descobrir aspectos da cultura estrangeira e, diante dessa nova descoberta, demonstra respeito (com isso não defendemos que o FI seja um indivíduo acrítico, mas que ele adote uma postura respeitosa ante a nova cultura);

- tem empatia, sendo capaz de se imaginar no lugar do outro e compreender que este possui outros valores e visões de mundo;

- tem conhecimento sobre os produtos e práticas da Cultura 1 (C1) e Cultura 2 (C2) (denotando-se aqui apenas a(s) velha(s) e a(s) nova(s) cultura(s), respectivamente, podendo elas serem mais de uma); assim, o FI é capaz de prever e evitar mal- 
Crespo, A.H.; Rozenfeld, C. - Protagonistas de séries voltadas para a aprendizagem de alemão entendidos e/ou situações desagradáveis decorrentes de divergências interculturais;

- é ciente de seus próprios valores e crenças e de como eles podem influenciar na sua concepção sobre o outro/novo.

Contudo, embora apresentemos essas características, vale ressaltar que, assim como pontuam Byram, Gribkova e Starkey (2002), não há um modelo perfeito e ideal de falante intercultural, uma vez que os conhecimentos e habilidades necessários para possuir uma boa competência intercultural estão sempre em construção e desenvolvimento.

Além disso, é comum que se pense em FI apenas como o estrangeiro. No entanto, um indivíduo que possua as características supracitadas em seu país de origem pode ser um falante intercultural, em virtude de experiências interculturais já vividas. Entendemos, porém, que House (2007) não tenha abarcado esse tipo de FI como modelo de aprendizagem, ou seja, um falante intercultural em sua $\mathrm{C} 1$ e desempenhando a sua L1, pois isso teria o mesmo efeito do falante nativo monolingual e monocultural sobre a aprendizagem de LE. Em outras palavras, os aprendizes de LE continuariam se espelhando na competência comunicativa de um falante desempenhando a sua língua nativa, o que, como já relatado, poderia gerar frustração nos alunos. Assim, tomamos um falante intercultural como aquele que não se encontra em seu país de origem e está, portanto, interagindo e inserido em práticas de uso da língua estrangeira na respectiva cultura-alvo. Além disso, o definimos como aquele que pode estar em um nível de proficiência linguística e intercultural mais ou menos avançada, podendo, assim, ser caracterizado como mais ou menos estável.

Tendo relatado as teorias que fundamentam a nossa análise, partimos na próxima seção para a metodologia empregada para a investigação deste trabalho. 
Crespo, A.H.; Rozenfeld, C. - Protagonistas de séries voltadas para a aprendizagem de alemão

\section{Metodologia}

Nesta seção explicaremos os critérios adotados para a análise dos falantes interculturais retratados nos seriados Erste Wege in Deutschland ${ }^{14}$ (Primeiros caminhos na Alemanha) e Jojo sucht das Glück ${ }^{15}$ (Jojo procura a sortela felicidade) e relataremos qual foi o recorte escolhido para esta investigação.

Tendo em vista o objetivo deste trabalho, analisamos as protagonistas dos referidos seriados: no primeiro, uma jovem turca e, no segundo, uma brasileira, ambas residentes na Alemanha. Tomando as características do falante intercultural que postulamos na seção dos pressupostos teóricos como norteadoras de análise, verificamos a possibilidade de categorizar as protagonistas como FI mais estáveis ou menos estáveis.

Assim sendo, refletimos acerca das seguintes questões ao analisar cada uma das protagonistas: 1) ela é capaz de interagir e se posicionar nas duas ou mais culturas/línguas em que se encontra? 2) ela apresenta traços que a caracterize como um indivíduo culturalmente híbrido? 3) ela lança mão de recursos discursivos provenientes do seu conhecimento de mais de uma língua/cultura? 4) ela demonstra interesse e respeito pela C2? 5) ela possui empatia pelos membros da C2? 6) ela conhece suficientemente bem os produtos e as práticas de sua $\mathrm{C} 1$ e $\mathrm{C} 2$ ? 7) ela tem consciência sobre os seus próprios valores e crenças?

Como recorte para a investigação, escolhemos o episódio 3, Bei der Arbeit (No trabalho) e o 8, der Handy-Vertrag (O contrato de celular), da minissérie Erste Wege in Deutschland, visto que, em nosso entendimento, são episódios nos quais podemos verificar mais claramente a caracterização dos protagonistas como falantes interculturais, pois expõem suas crenças, seu conhecimento linguístico, seu conhecimento da cultura estrangeira, os traços da sua cultura materna, etc.

No seriado Jojo sucht das Glück, analisamos os primeiros cinco episódios da primeira temporada, respectivamente: die Ankunft (A chegada), Jojo aus Brasilien (Jojo do Brasil), Eine Frau in der WG? (Uma mulher na república?), Begegnung auf dem Markt

\footnotetext{
14 Disponível em: <http://www.goethe.de/lrn/prj/wnd/deu/mse/deindex.htm?wt_sc=mwnd_miniserie>. Acesso em: 20 abr. 2018.

15 Disponível em: <http://www.dw.com/de/deutsch-lernen/jojo-staffel-1/s-31564>. Acesso em: 20 abr. 2018.
} 
Crespo, A.H.; Rozenfeld, C. - Protagonistas de séries voltadas para a aprendizagem de alemão

(Encontro na feira) e Döner und Currywurst (dois tipos de comida muito presentes no dia a dia alemão), tendo em conta que há uma continuidade entre as histórias. Além disso, vale ressaltar que a escolha de cinco episódios da referida série ao invés de dois (como escolhido para a análise da primeira série mencionada) se deve à curta duração de cada episódio de Jojo sucht das Glück, o que trouxe a necessidade de analisar mais material, a fim de termos uma melhor fundamentação para o nosso argumento.

Os resultados obtidos por meio de nossas análises são apresentados na seção a seguir.

\section{Análise dos dados: os falantes interculturais nas séries.}

Nesta seção descreveremos os dois seriados e traremos à luz da discussão as reflexões e considerações a respeito do tema investigado.

\subsection{Erste Wege in Deutschland}

Erste Wege in Deutschland é uma série que pode ser acessada na internet também sob o nome de Mein Weg nach Deutschland. Trata-se de uma minissérie de apenas uma temporada, que está disponível tanto no "Youtube" quanto no portal do Goethe Institut, no qual também estão disponibilizados exercícios com a temática de cada episódio. A minissérie possui oito episódios com duração média de sete minutos cada, sendo que o primeiro foi postado em fevereiro de 2013 e o último em abril de 2014. Achamos pertinente destacar que o vídeo da minissérie com mais visualizações (no caso, o primeiro episódio, intitulado im Bus) foi visto mais de um milhão de vezes até o momento da elaboração deste artigo.

O seriado gira em torno da história de Nevin, uma jovem turca, de 23 anos, que, em decorrência de seu casamento com um alemão, se muda para a Alemanha. ${ }^{16}$ Estando

\footnotetext{
${ }^{16}$ Já na temática central da série, vale problematizar o motivo apresentado para a mudança de Nevin para a Alemanha. A nosso ver, o fato de a protagonista ter se afastado de sua cultura para acompanhar o seu marido alemão já pode contribuir para uma retratação subalternizada de Nevin como mulher e como cidadã de um país não-hegemônico. Tal fato também pode ser ilustrado no episódio "Neue Freunde", no qual, nos primeiros momentos, acompanhamos a jovem turca na tarefa de preparar um bolo para receber o marido em casa ao final de seu expediente. Como alternativa, julgamos que poderiam ser apresentadas outras 
Crespo, A.H.; Rozenfeld, C. - Protagonistas de séries voltadas para a aprendizagem de alemão

no país estrangeiro há pouco tempo, atividades consideradas rotineiras transformam-se em verdadeiros desafios para Nevin, devido à sua dificuldade para se comunicar na LE e ao seu conhecimento supostamente precário sobre a língua e a cultura-alvo. Assim sendo, os episódios são centrados nessas pequenas atividades do dia a dia, tais como pegar ônibus, procurar um imóvel, fazer novos amigos, entre outras.

Conforme mencionamos na metodologia, nosso recorte estará nos episódios 3 (Bei der Arbeit) e 8 (der Handy-Vertrag), por possibilitarem uma melhor análise da protagonista como falante intercultural.

Consideramos relevante mencionar que, por meio de informações obtidas na internet, verificamos que a atriz que interpretou o papel de Nevin é na realidade de nacionalidade alemã (Sara Klapp) e nascida em Kassel. Como língua estrangeira, a atriz sabe falar inglês e francês, porém, não encontramos nenhuma informação sobre seu conhecimento da língua turca ou sobre qualquer origem ou contato que ela tenha com esse país. Entendemos que tal fato reafirma o conceito de falante nativo ideal proposto por Kramsch (1998), discutido na seção de pressupostos teóricos, dado que a atriz, embora seja uma falante nativa de alemão, foi designada a interpretar o papel de uma imigrante apenas em virtude de sua aparência física.

Voltando o olhar para os episódios em foco, nota-se que em "Bei der Arbeit" Nevin se encontra em seu primeiro dia de trabalho como vendedora de legumes. A jovem, representada como turca com nível de proficiência da língua alemã ainda muito baixo, demonstra certa dificuldade em desempenhar a tarefa à qual foi encarregada: selecionar alguns legumes e verduras com base em uma lista previamente fornecida. Com isso, a cena busca representar uma falante intercultural menos estável, por não ser capaz de realizar tarefas simples na cultura/língua estrangeira. Ela demonstra, porém, interesse em aprender novos vocábulos e se mostra entusiasmada quando reconhece uma palavra recém-aprendida, o que remete à atitude do falante intercultural em face a novas descobertas sobre o outro/novo.

Todavia, reconhecemos uma incoerência no papel de Nevin como falante intercultural, pois essa "pretensa" dificuldade da protagonista aparenta ser irreal, devido à produção de uma fala foneticamente equivalente à do falante nativo em contraposição

razões, pelas quais mulheres estrangeiras se mudam para a Alemanha, tais como obtenção de uma bolsa de estudos, busca por oportunidades de emprego, uma oferta de trabalho, etc. 
Crespo, A.H.; Rozenfeld, C. - Protagonistas de séries voltadas para a aprendizagem de alemão

a uma dificuldade de uma falante intercultural de baixa proficiência linguística. Nota-se, em sua produção linguística, que não estão presentes traços da identidade turca em sua discursividade, salvo pelos longos períodos de silenciamento que pretendem simular sua dificuldade. A despeito das pausas, sua produção oral parece se aproximar muito mais da do falante nativo, em sua pronúncia e prosódia, se aproximando das características do falante ideal.

Ademais, não se percebe interferências da L1 na L2, como se esperaria de um falante intercultural. A única interferência retratada ocorre em outra cena, nesse mesmo episódio, quando, ao ser indagada por uma cliente (sem óculos) sobre o nome de dado produto, Nevin recorre à sua língua materna, visto que não sabia como ele se chamava em alemão. Por uma felicidade do acaso, a palavra para designar o produto é a mesma em alemão e turco, uma vez que se trata de uma comida típica turca e Nevin, recémcontratada, conseguiu interagir na LE e evitar uma ruptura na comunicação. Embora reconheçamos que a escolha da palavra tenha sido um acerto ao acaso, identificamos na cena um hibridismo da personagem, bem como a sua capacidade de lançar mão de recursos discursivos para atingir um objetivo comunicativo.

Outro fato interessante que observamos neste episódio, é quando Nevin, um pouco atrapalhada com a função relatada acima, conta com a ajuda de uma conhecida, também imigrante, para organizar a prateleira do mercado. Consideramos essa cena significativa, pois visa retratar a situação de duas falantes interculturais, desempenhando uma atividade do dia a dia em uma cultura/língua estrangeira, sendo que a falante mais estável está auxiliando a menos estável, fato que representa adequadamente a noção de falante intercultural como modelo de aprendizagem.

Tendo em vista tais ponderações, acreditamos que essa cena possa ser trabalhada em sala de aula de forma a trazer os alunos para a reflexão de que não só o falante nativo é capaz de ajudar nessas situações e de que o sucesso em desempenhar tarefas é decorrente da experiência com a cultura/língua-alvo, independentemente se a pessoa é nativa ou não.

Em relação ao episódio "der Handy-Vertrag”, da mesma série, nos primeiros minutos é possível acompanhar Nevin caminhando pelo centro da cidade, até que ela atende o telefonema de uma amiga alemã, Sofie, convidando-a para sair. Após desligar o celular, a jovem turca é abordada na rua por uma vendedora, que tenta convencê-la a fechar um contrato com uma operadora de celular. Primeiramente julgamos importante destacar que notamos que se pretendeu representar na figura da protagonista, nesse 
Crespo, A.H.; Rozenfeld, C. - Protagonistas de séries voltadas para a aprendizagem de alemão

episódio, um maior desenvolvimento na proficiência linguística, tendo em vista tratar-se do último da minissérie, e que ela consegue se comunicar mais facilmente ao telefone e com seus interlocutores. Entretanto, também neste episódio, notamos algumas inconsistências: na cena, em um primeiro momento, Nevin é representada como uma falante ainda em desenvolvimento, porém eficiente; logo em seguida, ela se comporta como uma falante em desvantagem comunicativa, pois é enganada pela vendedora ao assinar o contrato de telefonia celular sem ter conhecimento de todos os dados do plano. A protagonista só percebe o equívoco quando Sofie, uma falante nativa, lê o contrato e aponta algumas informações sobre desvantagens do plano. A amiga explica a Nevin, assim, que é possível cancelar o contrato no período de duas semanas, uma informação sobre o universo cultural alemão que a protagonista certamente não tinha. Tal fato pode ser bastante comum para pessoas que vivenciam uma nova cultura, marcando, de forma bastante representativa, as vivências de um falante intercultural.

Consideramos importante na cena o fato de se alertar o aprendiz sobre adversidades e desentendimentos encontrados numa outra cultura. No entanto, House (2007) alerta para o fato de que os falantes interculturais menos estáveis são retratados em filmes, livros e seriados frequentemente como sujeitos em desvantagem, o que poderia desmotivar os aprendizes a adotarem uma postura ativa e de interesse, em face às novas descobertas de uma cultura/língua estrangeira, além de não contribuir para o desenvolvimento da competência intercultural dos mesmos. Assim, é importante que o professor problematize a situação, discutindo a verossimilhança da cena, mas também o fato de que isso não o desvaloriza como FI: a cena apenas retrata uma situação natural, que pode ocorrer inclusive com falantes nativos que, embora saibam decodificar os signos linguísticos, não são capazes de realizar uma leitura crítica da situação. ${ }^{17}$

Outra questão que nos parece importante de ser problematizada está na ajuda recebida por Nevin em diferentes episódios. Em "Bei der Arbeit", Nevin é ajudada por uma imigrante em uma tarefa muito simples, que exigia conhecimento básico da língua, mas, quando diante de um problema mais complexo, a ajuda veio de uma falante nativa, como no episódio "der Handy-Vertrag". Tal fato corrobora a problemática apontada por

\footnotetext{
17 Tal premissa pode ser encontrada na literatura sobre letramento crítico (SOARES 2000; JORDÃO 2013; SOARES 2014).
} 
Crespo, A.H.; Rozenfeld, C. - Protagonistas de séries voltadas para a aprendizagem de alemão

House (2012), pois relega o FI ao papel de alguém capaz de solucionar/auxiliar na solução de problemas menos complexos, que não exigem maior conhecimento linguístico.

Outro aspecto que nos chamou a atenção concerne ao trato de estereótipos. Notamos certa preocupação em não retratar a protagonista de forma estereotipada, característica importante de um FI. Todavia, acreditamos que essa preocupação levou a uma falta de caracterização da personagem como indivíduo híbrido. Se Nevin não tivesse características físicas tipicamente turcas, e o seu sobrenome não fosse mencionado, não se teria pistas sobre o seu país de origem. A nosso ver, a personagem poderia ser representada com mais referências a práticas de seu país de origem, ou acerca de seus valores e crenças, tendo em vista que isso é uma marca de sua identidade e, assim, a aproximaria das características de um falante intercultural.

Diante da discussão sobre a minissérie Erste Wege in Deutschland, podemos concluir que Nevin se trata de uma falante intercultural não estável, uma vez que ainda não consegue interagir, se posicionar e desempenhar todas as tarefas na cultura/língua estrangeira, tampouco tem um bom conhecimento sobre os produtos e práticas dessa cultura. Além disso, a protagonista mostra-se interessada em descobrir o novo/o outro, não se isolando em sua própria cultura, o que julgamos como algo bastante positivo para a caracterização da personagem. Por outro lado, há uma incoerência entre sua posição de falante intercultural estrangeira e sua produção oral do ponto de vista fonético/prosódico. Nota-se uma produção foneticamente irreal para uma falante intercultural não estável, como a que se deseja representar. Ademais, nota-se um apagamento da cultura e identidade turca na falante e uma maior preocupação com sua inserção na comunidadealvo. Tal fato não se alinha com a noção de falante intercultural, que circula entre duas culturas, sem perda de identidade ou marcas de assimilação.

Diante do exposto, trazemos na Quadro 1 algumas questões que nortearam a nossa análise sobre a caracterização de Nevin como FI, as quais já foram apresentadas na metodologia deste trabalho. Em seguida, passamos, na próxima seção, para a análise da protagonista do seriado Jojo sucht das Glück. 
Crespo, A.H.; Rozenfeld, C. - Protagonistas de séries voltadas para a aprendizagem de alemão

QUADRO 1

Aspectos para a caracterização da protagonista de Mein Weg nach Deutschland como FI

\begin{tabular}{|l|l|}
\hline $\begin{array}{l}\text { 1) ela é capaz de interagir e se posicionar } \\
\text { nas duas ou mais culturas/línguas em que } \\
\text { se encontra? }\end{array}$ & $\begin{array}{l}\text { Ao longo da série, observamos um } \\
\text { progresso da personagem quanto a sua } \\
\text { capacidade de interação na L2/C2. }\end{array}$ \\
\hline $\begin{array}{l}\text { 2) ela apresenta traços que a caracterizem } \\
\text { como um indivíduo culturalmente } \\
\text { híbrido? }\end{array}$ & $\begin{array}{l}\text { Não. Salvo os seus traços físicos e o seu } \\
\text { nome e sobrenome, Nevin não apresenta } \\
\text { mais nenhuma característica que remeta à } \\
\text { cultura turca. No âmbito linguístico, a } \\
\text { protagonista também apresenta uma } \\
\text { pronúncia e uma prosódia muito próximas } \\
\text { do falante nativo alemão. }\end{array}$ \\
\hline $\begin{array}{l}\text { 3) ela lança mão de recursos discursivos } \\
\text { provenientes do seu conhecimento de } \\
\text { mais de uma língua/cultura? }\end{array}$ & $\begin{array}{l}\text { Sim, como apontado no primeiro episódio } \\
\text { analisado. }\end{array}$ \\
\hline $\begin{array}{l}\text { 4) ela demonstra interesse e respeito pela } \\
\text { C2? }\end{array}$ & $\begin{array}{l}\text { Sim, pois se interessa em conhecer o } \\
\text { novo/o outro. }\end{array}$ \\
\hline $\begin{array}{l}\text { 5) ela possui empatia pelos membros da } \\
\text { C2? }\end{array}$ & Não foi possível ser analisado. \\
\hline $\begin{array}{l}\text { 6) ela conhece suficientemente bem os } \\
\text { produtos e as práticas de sua C1 e C2? }\end{array}$ & $\begin{array}{l}\text { Não. Como retratado no episódio “der } \\
\text { Handy-Vertrag”, Nevin desconhece a } \\
\text { prática de se fechar um contrato com uma } \\
\text { rede de telefonia celular. }\end{array}$ \\
\hline $\begin{array}{l}\text { 7) ela tem consciência sobre os seus } \\
\text { próprios valores e crenças? }\end{array}$ & Não foi possível ser analisado. \\
\hline
\end{tabular}

Fonte: Elaboração própria para este trabalho.

\subsection{Jojo sucht das Glück}

O seriado Jojo sucht das Glück pode ser acessado no "Youtube", ou no site do jornal alemão Deutsche Welle, na seção destinada para a aprendizagem de língua alemã. Jojo sucht das Glück possui três temporadas, sendo a primeira de 2011, a segunda de 2012 e a terceira de 2014. Cada temporada contém 33 episódios de duração média de dois minutos e meio. Podemos inferir a popularidade do seriado pelo fato de o primeiro episódio da primeira temporada ter sido acessado no "Youtube" mais de meio milhão de vezes.

Acerca da trama, Jojo é uma brasileira de Maceió que se muda para a cidade de Colônia na Alemanha. Ao chegar ao seu apartamento, que supostamente ela dividiria com mais duas moças, ela descobre que houve uma falha de comunicação e que ela terá que 
Crespo, A.H.; Rozenfeld, C. - Protagonistas de séries voltadas para a aprendizagem de alemão

morar com dois homens, ambos também surpresos com a descoberta, pois esperavam que Jojo fosse um homem.

Assim como na análise anterior, achamos relevante destacar que a atriz que interpreta a protagonista do seriado não é brasileira. Dorothea Kriegl nasceu na Alemanha, na cidade de Wolfach, e, aparentemente, não tem qualquer conexão com o Brasil. A partir de nossa análise, notamos que Jojo, diferentemente de Nevin, não encontra dificuldade alguma em realizar as tarefas do dia a dia; ao contrário, ela parece se adaptar perfeitamente, como uma falante nativa, à cultura estrangeira. Assim, a personagem não remete o espectador à realidade de um estrangeiro fora de seu país de origem. Também a sua pronúncia, sua escolha de palavras, seu jeito de se vestir e de se expressar estão bastante próximos do que é mais tipicamente encontrado entre os alemães nativos, demonstrando um distanciamento das características de um falante intercultural. Dessa forma, se Jojo não tivesse informado no seriado que vem de Maceió, não haveria qualquer indício de que ela é brasileira, até o episódio cinco, quando ela relata a sua nova amiga o costume que temos de dar apelidos e nomes carinhosos uns aos outros. Além disso, vale destacar que, quando a personagem se apresenta para os seus novos colegas de casa, ela pronuncia o seu próprio nome, Joceline Rocha Santos, com forte sotaque alemão, fato que reafirma ao espectador a artificialidade da situação e da personagem.

Outro aspecto que nos chamou a atenção foi o fato de não ter havido, até o episódio cinco, qualquer indicação acerca da forma como a protagonista aprendeu alemão. Julgamos que a sua caracterização como uma FI com produção oral similar ao falante nativo seria justificável apenas se Jojo fosse filha de alemães ou uma alemã que passou grande parte da vida no Brasil. No entanto, a impressão que o seriado passa ao espectador é a de que a protagonista chegou ao país pela primeira vez e está tendo seus primeiros contatos com a cultura-alvo, constituindo, assim, uma incoerência. Outra incoerência está no fato de que Jojo, representada como uma falante fluente, que aparenta em algumas situações não ter problema algum de adaptação, não sabe o que são Döner e Currywurst, comidas que pertencem ao dia a dia da cultura alemã e que, portanto, deveriam ser conhecidas por turistas que tenham algum conhecimento sobre a cultura local.

Isto posto, concluímos que Jojo não representa uma falante intercultural como modelo de aprendizagem, tendo em vista que ela é retratada de forma idealizada, inverossímil e em relação de grande semelhança a uma falante nativa. Nota-se que não há traços na personagem que demonstrem seu hibridismo cultural e a sua identidade como

Pandaemonium, São Paulo, v. 21, n. 35, set.-dez. 2018, p. 170-201 
Crespo, A.H.; Rozenfeld, C. - Protagonistas de séries voltadas para a aprendizagem de alemão

uma brasileira. Ademais, nos episódios analisados, em nenhum momento Jojo recorreu ao seu conhecimento da língua materna, seja para expressar algo de forma espontânea ou como recurso discursivo, o que nos leva a crer que a personagem não possui as vantagens comunicativas de um falante intercultural postuladas por House (2007).

Nota-se ainda a representação na série de alguns estereótipos. Em uma das primeiras falas da protagonista, por exemplo, após um desconhecido trombar com Jojo na rua, ela comenta que "se fosse em São Paulo, a minha carteira não estaria mais aqui" (tradução nossa). ${ }^{18}$ Pensamos que esse comentário contribui para uma visão negativa dos alunos de alemão sobre si mesmos (no caso dos alunos brasileiros) ou sobre este povo e para a propagação de uma imagem estereotipada. Os alemães, por outro lado, não são todos caracterizados na série de forma estereotipada, visto que uma grande maioria é amável, contrariando a imagem comum de frieza do alemão, e, embora um dos personagens seja bastante grosseiro com a protagonista, isso é justificado pelo fato de ele estar passando por uma fase ruim, além de se subentender que os dois serão o par amoroso da trama, logo, esse suposto desafeto representa o famoso clichê do casal romântico que inicialmente não gosta um do outro. Julgamos positivo que não haja muitos estereótipos ao retratar os alemães, o que incita a aproximação dos alunos com a cultura/língua-alvo, além de motivá-los a aprender e um dia visitar os países falantes de língua alemã. No entanto, esperávamos que o mesmo ocorresse em relação à personagem brasileira.

Considerando a discussão abordada nesta seção, sintetizamos no Quadro 2 as questões que nos auxiliaram na análise sobre a caracterização de Jojo como FI. Tendo finalizado as análises propostas, passamos, então, para as considerações finais do trabalho.

\section{QUADRO 2}

Aspectos para a caracterização da protagonista de Jojo sucht das Glück como FI

\begin{tabular}{|l|l|}
\hline $\begin{array}{l}\text { 1) ela é capaz de interagir e se posicionar } \\
\text { nas duas ou mais culturas/línguas em que } \\
\text { se encontra? }\end{array}$ & $\begin{array}{l}\text { Sim. No entanto, a sua proficiência na } \\
\text { língua estrangeira é igual à de um falante } \\
\text { nativo. }\end{array}$ \\
\hline $\begin{array}{l}\text { 2) ela apresenta traços que a caracterizem } \\
\text { como um indivíduo culturalmente } \\
\text { híbrido? }\end{array}$ & $\begin{array}{l}\text { Não, uma vez que é retratada como uma } \\
\text { falante nativa ideal de alemão. }\end{array}$ \\
\hline
\end{tabular}

${ }^{18}$ No original: “In São Paulo wäre mein Portemonnaie bestimmt weg”. 
Crespo, A.H.; Rozenfeld, C. - Protagonistas de séries voltadas para a aprendizagem de alemão

\begin{tabular}{|c|c|}
\hline $\begin{array}{l}\text { 3) ela lança mão de recursos discursivos } \\
\text { provenientes do seu conhecimento de } \\
\text { mais de uma língua/cultura? }\end{array}$ & Não. \\
\hline $\begin{array}{l}\text { 4) ela demonstra interesse e respeito pela } \\
\text { C2? }\end{array}$ & $\begin{array}{l}\text { Sim, a protagonista se mostra } \\
\text { entusiasmada diante do novo/outro. }\end{array}$ \\
\hline $\begin{array}{l}\text { 5) ela possui empatia pelos membros da } \\
\text { C2? }\end{array}$ & Não foi possível ser analisado. \\
\hline $\begin{array}{l}\text { 6) ela conhece suficientemente bem os } \\
\text { produtos e as práticas de sua } \mathrm{C} 1 \text { e } \mathrm{C} 2 \text { ? }\end{array}$ & $\begin{array}{l}\text { Não, pois desconhece pratos comuns do } \\
\text { cotidiano alemão, como o Döner e o } \\
\text { Currywurst. }\end{array}$ \\
\hline $\begin{array}{l}\text { 7) ela tem consciência sobre os seus } \\
\text { próprios valores e crenças? }\end{array}$ & Não foi possível ser analisado. \\
\hline
\end{tabular}

Fonte: elaboração própria para este trabalho

\section{Considerações finais}

Neste trabalho, buscamos caracterizar os falantes interculturais de duas séries (Mein Weg nach Deutschland, produzida pelo Instituto Goethe, e Jojo sucht das Glück, pela Deutsche Welle). Destacamos que, embora as séries sejam materiais elaborados com fins pedagógicos, trata-se de insumo que possui algumas características semelhantes às de materiais autênticos, como a linguagem multimodal e o seu formato em episódios (como muitos seriados produzidos com objetivo de entretenimento). Assim, propomos tais séries como material semi-autêntico, no sentido de Andrade e Silva (2017), que tem grande vantagem em sala de aula e, nesse sentido, defendemos a pertinência de uma discussão mais aprofundada sobre seus elementos.

Com base nas discussões sobre falante e competência intercultural, propomos características relativas ao falante intercultural mais estável, como preconizado por House (2007), o qual pode ser visto como modelo de aprendizagem para os aprendizes de LE. Essas características, assim como a presença de estereótipos e de traços que conferem autenticidade aos materiais didáticos, foram utilizadas como critério para a nossa análise sobre as protagonistas dos seriados voltados para o ensino e aprendizagem de língua alemã Erste Wege in Deutschland e Jojo sucht das Glück.

Considerando que na Alemanha há grande número de imigrantes e de seus descendentes, sobretudo turcos, questionamos os critérios que foram utilizados para a seleção das atrizes em questão. Não nos parece que haveria qualquer dificuldade em encontrar uma atriz que também fosse uma falante intercultural estável, ou seja, 
Crespo, A.H.; Rozenfeld, C. - Protagonistas de séries voltadas para a aprendizagem de alemão

estrangeira, vivendo na Alemanha, o que, na nossa concepção, teria conferido maior autenticidade aos dois seriados analisados. Acreditamos que a escolha por uma falante nativa se deva à preocupação de não se reproduzir "desvios" da língua, os quais são comumente atribuídos aos falantes interculturais, e de representar a língua padrão. Dessa forma, mantém-se a crença de que o falante nativo é o melhor modelo de aprendizagem, mesmo quando interpreta um estrangeiro.

Por fim, chegamos à conclusão de que Nevin, protagonista de Erste Wege in Deutschland, se apresenta como uma alternativa melhor de representação de falante intercultural em comparação com Jojo, dado que a caracterização da jovem turca retrata de forma mais fidedigna uma falante intercultural, abordando a evolução de sua competência comunicativa, as suas dificuldades de adaptação e a sua curiosidade e interesse perante a cultura e língua estrangeira. Jojo, por sua vez, comunica-se bem mais eficientemente na LE do que Nevin, contudo, acreditamos que a protagonista de Jojo sucht das Glück é retratada como uma falante nativa, tornando-se uma representação artificial e idealizada de uma estrangeira.

Todavia, devemos ressaltar que o resultado apresentado neste trabalho não significa que os seriados não possam ser utilizados como recursos didáticos ou que a exibição de Erste Wege in Deutschland por si só seja suficiente para que o aluno melhore as suas habilidades como falante intercultural. Defendemos que ambos os seriados podem ser utilizados em atividades em sala de aula, desde que o professor os insira dentro de objetivos pedagógicos condizentes com o programa de ensino, reflita sobre a prática com esses materiais e estimule em seus aprendizes uma visão e um posicionamento crítico sobre o material apresentado.

Ademais, esperamos que este trabalho possa servir futuramente como ferramenta para os profissionais da área da educação analisarem criticamente a representação de falantes interculturais em séries e filmes, de modo que, com o nível de exigência dos consumidores cada vez maior, os produtores/elaboradores de materiais audiovisuais se tornem mais atentos para a problemática da retratação estereotipada, idealizada e irreal desse grupo de falantes. 
Crespo, A.H.; Rozenfeld, C. - Protagonistas de séries voltadas para a aprendizagem de alemão

\section{Referências bibliográficas}

ANDRAdE E SILVA, Mariana Kuntz de. Authenticity of materials and foreign language teaching. Pandaemonium Germanicum, São Paulo, v. 20, n. 31, p. 1-29, 2017.

Araujo, Alda Regina; Voss, Rita de Cássia Ribeiro. Cinema em Sala de Aula: identificação e projeção no ensino/aprendizagem da Língua Inglesa. Conexão - Comunicação e Cultura, v. 8, n. 15, p. 119-130, 2009.

BAUMAN, Zygmunt. A cultura no mundo líquido moderno. Tradução de Carlos Alberto Medeiros. Rio de Janeiro: Zahar, 2013.

BAX, Stephen. CALL: past, present and future. System. v. 31, n. 1, p. 13-28, 2003. Disponível em: $\quad$ http://hstrik.ruhosting.nl/wordpress/wpcontent/uploads/2013/03/Bax-CALLSystem-2003.pdf>. Acesso em: 02 abr. 2018.

BERARDO, Sacha Anthony. The use of authentic materials in the teaching of reading. The Reading Matrix, v. 6, n. 2, p. 60-69, 2006.

BUSNARDO, Joanne. Contextos pedagógicos e conceitos de cultura no ensino de línguas estrangeiras. In: SANTOS, Percilia; ALVARES, Maria Luiza Ortiz (Org.). Língua e cultura no contexto de português língua estrangeira. Campinas: Pontes, 2010. p. 123-139.

BYRAM, Michael; GrIBKOVA, Bella; STARKEY, Hugh. Developing the Intercultural Dimension in Language Teaching: A Practical Introduction for Teachers. Graz: Council of Europe, $2002 . \quad$ Disponível em: <http://lrc.cornell.edu/rs/roms/507sp/ExtraReadings/Section0/Section0/uploads/File123 5272745204/InterculturalDimensionByram.pdf>. Acesso em: 18 abr. 2018.

Carvalho, Ana Amélia Costa da Conceição Amorim Soares de. Materiais autênticos no ensino das línguas estrangeiras. Revista Portuguesa de Educação, v. 6, n. 2, p. 117-124, 1993.

CRUZ, Maria de Lourdes O. B.; SouZA, Fábio Marques; GAMA, Angela Patrícia Felipe. O cinema no aperfeiçoamento das competências do aprendiz de línguas (materna e estrangeira). In: PROGRAD UNESP (Org.). Livro eletrônico dos núcleos de ensino da UNESP. São Paulo: Cultura Acadêmica Editora, 2007. p. 487-499.

DERVIN, Fred. Cultural identity, representation and othering. In: JACKSON, Jane. The Routledge Handbook of Language and Intercultural Communication. New York: Routledge, 2014. p. 181-194.

DOURADO, Maria Regina; Poshar, Heliane. A. A cultura na educação linguística no mundo globalizado. In: SANTOS, Percilia; Alvarez, Maria Luiza Ortiz (Org.). Lingua e cultura no contexto de português língua estrangeira. Campinas: Pontes, 2010. p. 33-52.

DÖRNYEI, Zoltan. Motivation and Motivating in the Foreign Language Classroom. The Modern Language Journal, v. 78 n. 3, p. 273-284, 1994.

ERSTE Wege In Deutschland. Direção de Hanni Welter. Produção de Sonja Hachenberger. [s.i]: Context Film/ Goethe Institut, 2013. Son., color. Disponível em: <https://www.youtube.com/watch?v=RyqRbeNS3-o>. Acesso em: 17 fev. 2018.

House, Juliane. What Is an 'Intercultural Speaker'? In: AlCón SOLER, Eva; SAFONT JORDÀ, Maria Pilar (Org.). Intercultural Language Use and Language Learning. Netherlands: Springer, 2007. p. 7-21.

JOJO SUCHT DAS GLÜCK. Direção de Mathias Laermanns. Produção de Mathias Laermanns. [s.i]: Dw, 2011. Son., color. Legendado. Disponível em: <https://www.youtube.com/watch?v=A5xmAlPXBBM>. Acesso em: 18 abr. 2018.

JORDÃO, Clarissa Menezes. Abordagem comunicativa, Pedagogia Crítica, Letramento Crítico: farinhas do mesmo saco? In: RoCHA, Claudia Hilsdorf; MACIEL, Ruberval Franco. (Org.). Língua Estrangeira e formação cidadã: por entre discursos e práticas. Campinas: Editora Pontes, 2013. p. 69-90. 
Crespo, A.H.; Rozenfeld, C. - Protagonistas de séries voltadas para a aprendizagem de alemão

KRAMSCH, Claire. Language and Culture. Oxford: Oxford University Press, 1998.

KRAMSCH, Claire. Language and Culture. In: SIMPSON, James (Org.). The Routledge Handbook of Applied Linguistics. New York: Routledge, 2011. p. 305-317.

LEFFA, Vilson. O ensino de línguas mediado por computador. In: Pesquisa em Linguística Aplicada: Temas e métodos. Pelotas: Educat, 2006. p. 11-36. Disponível em: $\langle$ http://www.leffa.pro.br/textos/trabalhos/B_Leffa_CALL_HP.pdf >. Acesso em: 03 abr. 2018.

MARQues, Lívia dos Santos; RozenFeld, Cibele Cecílio de Faria. The usage of television series in german language teaching: linguistic, sociocultural, ideological and social-political aspects in Deutschland 83. Pandaemonium Germanicum, São Paulo, v. 21, n. 33, p. 6486, 2017.

Moran, José Manuel. O vídeo na sala de aula. Comunicação \& Educação, n. 2, p. 27-35, jan.abr. 1995.

NEUNER, Gerhard; HunFELD, Hans. Methoden des fremdsprachlichen Deutschunterrichts: Eine Einführung. Kassel: Langenscheidt, 1993.

OLIVEIRA, Adelaide P. Tips for Teaching Culture in a Globalized World. In: LIMA, Diógenes Cândido de (Org.). Language and its cultural substrate: perspectives for a globalized world. Campinas: Pontes, 2012. p. 83-107.

PAIVA, Vera Lúcia Menezes de Oliveira. O uso da tecnologia no ensino de línguas estrangeiras. In: JESUS, Dánie Marcelo de; MACIEL, Ruberval Franco. (Org.). Olhares sobre tecnologias digitais: linguagens, ensino, formação e prática docente. Campinas: Pontes Editoras, 2015. p. 21-34.

PIRES, Ana Cristina Antunes. O Cinema na Sala de Aula: Contributos sobre a utilização de cinema na aula de língua estrangeira (Espanhol). 2011. Tese (Mestrado em Ensino do Português). Faculdade de Letras, Universidade do Porto, Porto, 2011.

Rajagopalan, K. For the Umpteenth Time, the "Native Speaker": Or, Why the Term Signifies Less and Less in the Case of English as It Spreads More and More Throughout the World. In: LIMA, Diógenes Cândido de (Org.). Language and its cultural substrate: perspectives for a globalized world. Campinas: Pontes, 2012. p. 37-58.

RoDRIGUES, Luiz Carlos Balga. A Formação do Professor de Língua Estrangeira no Século XXI: entre as antigas pressões e os novos desafios. Signum: Estudos da Linguagem, Londrina, v. 2, n. 19, p. 13-34, dez. 2016. Disponível em: <http://www.uel.br/revistas/uel/index.php/signum/article/view/21848/20215>. Acesso em: 15 abr. 2018.

RoJo, Roxane Helena Rodrigues. Pedagogia dos multiletramentos: diversidade cultural e de linguagens na escola. In: RoJO, Roxane Helena Rodrigues; MouRA, Eduardo (Org.). Multiletramentos na escola. São Paulo: Parábola Editorial, 2012. p. 11-32

ROZENFELD, Cibele Cecílio Faria; VIANA, Nelson. O desestranhamento em relação ao alemão na aprendizagem do idioma: um processo de aproximação ao "outro" sob a perspectiva da competência intercultural. Revista Pandaemonium Germanicum, v. 17, p. 259-288, 2011. Disponível em: 〈http://www.revistas.usp.br/pg/article/view/38109>. Acesso em: 01 abr. 2018.

RozenFELD, Cibele Cecilio de Faria; MARQUES-SCHÄFER, Gabriela. Tecnologias móveis e o ensino de línguas estrangeiras: explorando conceitos e práticas. In: LUCAS, Patricia de Oliveira; RODRIGUES, Rosana Ferrareto Lourença (Org.). Temas e rumos nas pesquisas em Línguística (Aplicada): questões empíricas, éticas e práticas. v. 2. Campinas, SP: Pontes Editores, 2017. p. 229-254.

SANCHO, Juana María. De tecnologias da informação e comunicação a recursos educativos. In: SANCHO, Juana María e HERNANDEZ, Fernando (Org.). Tecnologias para transformar a educação. Porto Alegre: Editora Artmed, 2006. p. 15-41. 
Crespo, A.H.; Rozenfeld, C. - Protagonistas de séries voltadas para a aprendizagem de alemão

SALOMÃO, Ana Cristina Biondo. O componente cultural no ensino e aprendizagem de línguas: desenvolvimento histórico e perspectivas na contemporaneidade. Trabalhos em Linguística Aplicada, v. 54, n. 2, p. 361-392, 2015.

SOARES, Erika Amâncio Caetano. O letramento crítico no ensino de língua inglesa: identidades, práticas e percepções na formação do aluno-cidadão. Dissertação (Mestrado em Linguística Aplicada). Faculdade de Letras, UFMG, Belo Horizonte, 2014.

SOARES, Magda. Letramento: um tema em três gêneros. Belo Horizonte: Editora Autêntica, 2000.

STANKE, Roberta Sol. Landeskunde na formação universitária do professor de alemão como língua estrangeira. In: BOLACIO FILHO, Ebal Sant'anna; FUNK, Hermann. Kulturdidaktik im Unterricht Deutsch als Fremdsprache: Deutsch lehren und lernen kooperativkompetent-kreativ. Rio de Janeiro: Apa-rio, 2014. p. 201-218.

SteFAnI, Viviane Cristina Garcia de. O Cinema na aula de língua estrangeira: uma proposta didático-pedagógica para o ensino-aprendizagem de espanhol. 2010. Dissertação (Mestrado em Ciências Humanas). Centro de Educação e Ciências Humanas, UFSCAR, São Carlos, 2010.

TAVARES, Roseanne Rocha. Conceitos de cultura no ensino/aprendizagem de línguas estrangeiras. In: (Org.). Língua, cultura e ensino. Maceió: EDUFAL, 2006. p. 1727.

VIEIRA-ABRAHÃO, Maria Helena. Algumas reflexões sobre a abordagem comunicativa, o pósmétodo e a prática docente. Revista EntreLínguas, v. 1, n. 1, p. 25-41, 2015. 